\title{
INSIGHTS INTO NORTH MESOPOTAMIAN 'METALLIC WARE'*
}

\author{
T. BROEKMANS
}

University of Antwerp, Department of Chemistry, Universiteitsplein 1, B-2610 Antwerp, Belgium

\author{
A. ADRIAENS $\dagger$ \\ Ghent University, Department of Analytical Chemistry, Krijgslaan 281-S12, B-9000 Ghent, Belgium \\ and E. PANTOS
}

CCLRC, Daresbury Laboratory, Warrington WA4 4AD, UK

\begin{abstract}
With the aim of shedding new light on the still poorly understood North Mesopotamian metallic ware, ceramic and soil samples from Tell Beydar (northeastern Syria, third millennium $B C$ ) were investigated using a range of analytical techniques, including optical microscopy, SR-XRD and SEM-EDX. The objective of this work was to differentiate calcareous metallic ware from non-calcareous ware without the aid of chemical analyses and to find further validation of the existing hypothesis that the former group is an imitation of the latter. A third group of metallic wares from Tell Beydar is believed to be of non-local, still regional origin.
\end{abstract}

KEYWORDS: TELL BEYDAR, NORTHERN MESOPOTAMIA, EARLY BRONZE AGE, METALLIC WARE, CERAMICS, POLARIZING MICROSCOPY, SR-XRD, SEM-EDX, TECHNOLOGY, PROVENANCE

\section{INTRODUCTION}

'Typical' metallic ware is generally made using very dense clay, which is free of large inclusions (Fig. 1). It is thrown on a fast wheel, smaller vessels being thrown from the hump (van As and Jacobs 1997, 51-4). The vessel colour is determined by the prevailing firing atmosphere. Very often, it is grey as a result of a reducing atmosphere, but it can also be reddish brown to orange when fired in an oxidizing atmosphere, or even a combination of these colours. As one of the more exclusive wares of its time, metallic ware usually does not constitute more than $5 \%$ of the total ceramic assemblage of the sites at which it is found.

In general, metallic ware is said to be easily differentiable from other contemporary pottery by its colour, texture, hardness and shape. However, today it is clear that not only a very dense, hard and usually dark-coloured kind of pottery exists, but also different varieties or 'lookalikes' are known. Being first found in the 1930s, it was not until 1976 that metallic ware was thoroughly described and discussed by Hartmut Kühne in his study of third millennium BC 


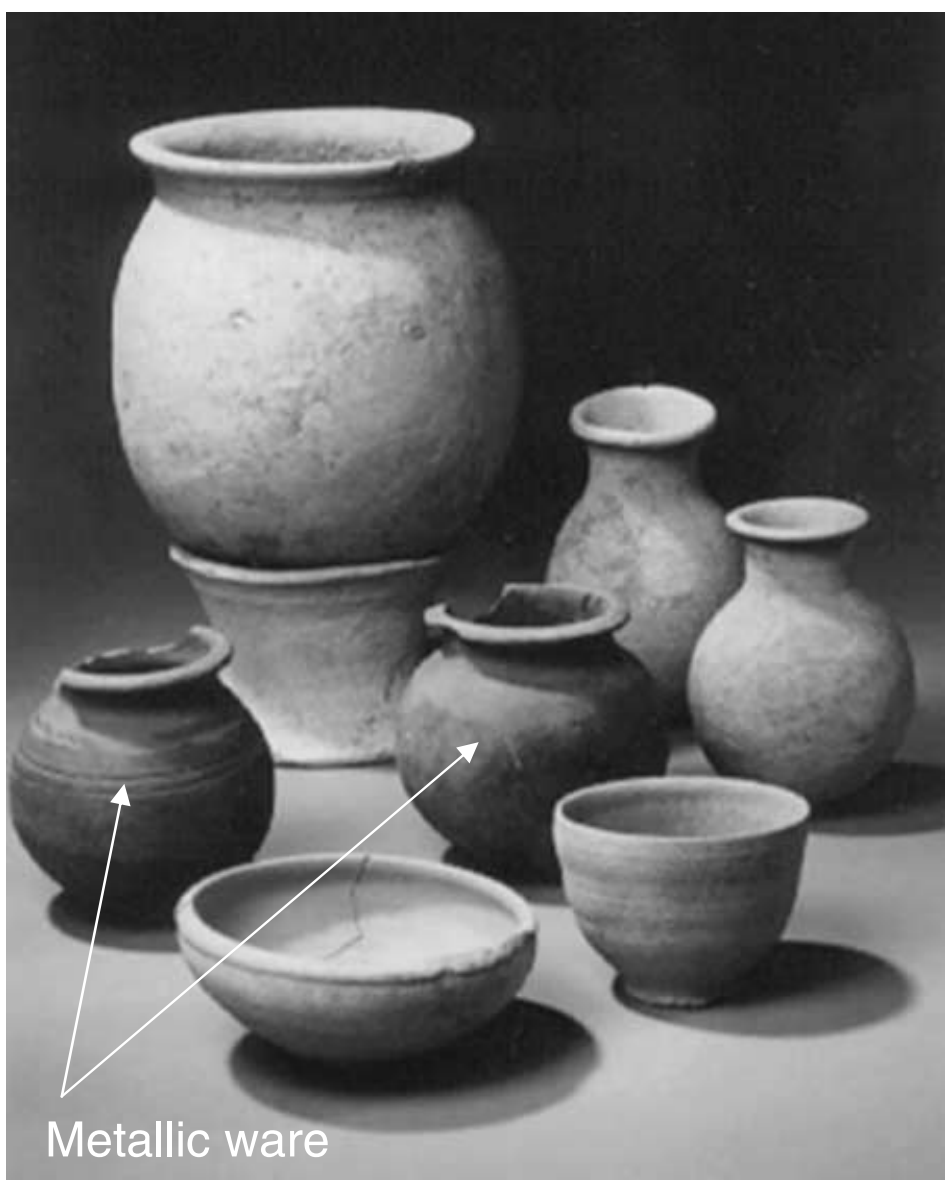

Figure 1 Metallic ware jars (indicated by arrows) from Tell Beydar, surrounded by contemporary standard ware. Reproduced with permission from Brepols Publishers.

pottery from Tell Chuera (Kühne 1976, 33-72). The term 'metallic ware' was introduced because of the supposed resemblance of the pottery to contemporary metal vessels (Kühne 1976, 33). Both before and after Kühne's study, several other names were, and are still, in use. This is especially the case for the term 'stone ware', which has mainly been used by the excavators of Tell Brak (Oates et al. 2001).

Besides all this, other wares in other cultural areas in the eastern Mediterranean (which have nothing to do with the pottery under discussion in this paper) have also been labelled as metallic ware. Examples can be found in the Amuq (Braidwood and Braidwood 1960, 370-1, 516) and in Anatolia (Mellaart 1966, 233, 234).

Working towards a better understanding of this complicated situation, Schneider and co-workers analysed a large set of metallic ware samples originating from different North Mesopotamian sites, resulting in the establishment of a group of 'real' non-calcareous metallic wares, most probably of non-local (i.e., non-Syrian) origin, and a group of calcareous metallic wares, believed to be local imitations of the 'real' ones (Kühne and Schneider 1988; Schneider 
1989). While this extensive and fundamental study provided important new information on and insight into metallic ware, new questions had evolved from it. Even though Kühne and Schneider's study was the ideal springboard for further research on metallic ware, not so much has been done since, except for more recent work from the same research group (Schneider and Daszkiewicz 2001).

The general aim of our study is threefold. First, we want to elaborate the existing differentiation of non-calcareous from calcareous metallic ware in the field, without the aid of chemical analyses. Second, we want to define which groups of metallic ware are represented at Tell Beydar. Finally, we want to understand the relationship between calcareous metallic ware and standard ware.

\section{ANALYSES OF TELL BEYDAR POTTERY}

Tell Beydar, the site at which our studied material was excavated, is situated in northeastern Syria along the Wadi 'Awaj, some $35 \mathrm{~km}$ north of the modern town of Hassake (Fig. 2). Although traces of Mitanni and Neo-Assyrian, as well as Seleuco-Parthian, settlements have been excavated, the main period of occupation was the third millennium BC (Lebeau and Suleiman 1997). During this period, Tell Beydar, the ancient town of Nabada, was a middlesized town of about 28 ha that was dominated by the city of Nagar, present-day Tell Brak.

A total of 53 metallic ware samples from Tell Beydar, seven from Tell Brak and two from Tell Jemello (situated about $6 \mathrm{~km}$ south of Tell Beydar) were studied. Both 'typical' pieces as well as metallic ware 'look-alikes' or 'imitations' are represented. In addition to metallic ware, 50 standard ware samples, four clay samples, four seal impressions and one object in unbaked

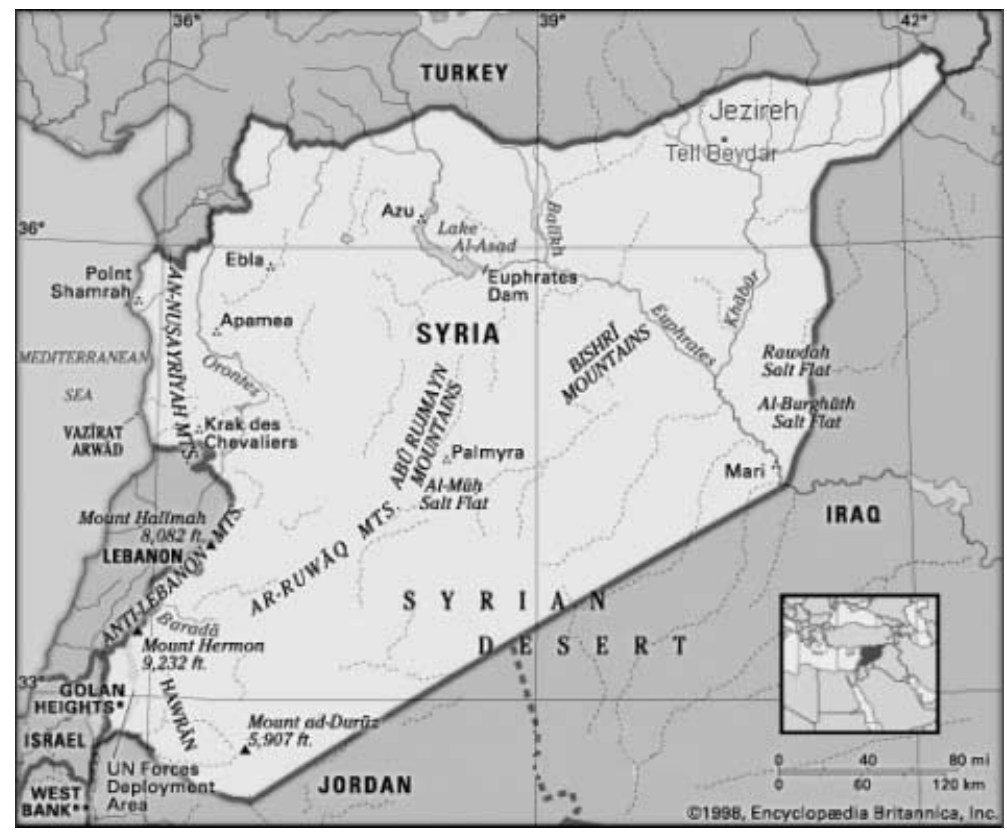

Figure 2 A map of Syria, showing the locations referred to in the text. 
clay from Tell Beydar are included in our study. While it is not always clear in case of clay samples whether the clay bed that they were derived from was accessible or even existed in the third millennium $\mathrm{BC}$, we know for sure that the clay used in ancient times is represented by the seal impressions and the unbaked clay object (although the same clay would not necessarily have been used for pottery production).

A preliminary investigation of the sherds was carried out by visual inspection and using optical microscopy with reflected light, usually the sole techniques that can be applied by archaeologists in the field. In this way, one obtains a first impression of the structure of the material, while several mineral inclusions within the paste matrix can already be identified. For further identification and description of mineral inclusions and for a more thorough description of the fabric as a whole, polarizing microscopy was applied.

In addition, 70 samples were subjected to X-ray diffraction by means of synchrotron radiation (SR-XRD) at station 9.6 of the synchrotron radiation source at Daresbury Laboratory (UK). The data collection and analysis procedures used for XRD were identical to those of a preceding study on cooking pottery from the same site and are described in Broekmans et al. (2004).

Elemental and imaging information was obtained by scanning electron microscopy with an energy-dispersive X-ray detector (SEM-EDX). As a sample preparation, the sherds were first embedded in a resin and cross-sectioned, whereupon their sections were gradually smoothened using waterproof abrasive paper. Finally, most of the samples were polished. The instrument (JEOL JSM-6300) was operated using a $20 \mathrm{keV}, 1 \mathrm{nA}$ electron beam to bombard the samples, and signals were accumulated over a period of $100 \mathrm{~s}$ (live time). Several areas of $10-25 \mathrm{~mm}^{2}$ of the sample's cross-section were rastered, the exact size of the area and the number of places scanned depending on the size of the sample. Since standard ware and metallic ware is always (relatively) fine grained (no large inclusions are present), heterogeneity does not pose a problem for this method of bulk composition determination. To obtain quantitative results, standardless ZAF corrections were used. In general, SEM-EDX is not a preferred technique for highprecision quantitative analyses, but it was chosen here because imaging information can be obtained at the same time.

\section{RESULTS}

A preliminary investigation of the metallic ware samples using optical microscopy with a low magnification divided the sample set into two groups on the basis of the presence or absence of macroscopically visible inclusions (MVIs) (Figs 3 (a) and 3 (b)). The visible inclusions were mainly quartz and a calcium-bearing mineral (a reaction with hydrochloric acid was observed). Often, black inclusions, thought to be magnetite, were also detected. The matrix of the samples without visible inclusions is more compact than that of the other samples.

The twofold division was confirmed when investigating thin sections of the samples using polarizing microscopy, in that the samples in the group with MVIs differ from all other samples regarding the type, size and amount of mineral inclusions. However, the group without MVIs could be further subdivided, thus resulting in three petrological metallic ware groups, as follows: group 1, samples with MVIs (mainly quartz and limestone, total inclusions 10-15\%); group 2, samples without MVIs, still having about $10 \%$ of small mineral inclusions (mainly quartz and K-feldspar); group 3, samples with hardly any inclusions whatsoever, resulting in a very dense fabric. The two latter groups cannot be differentiated with the naked eye or under low magnification.

In a following step, the mineral phase composition was analysed using SR-XRD. Apart 

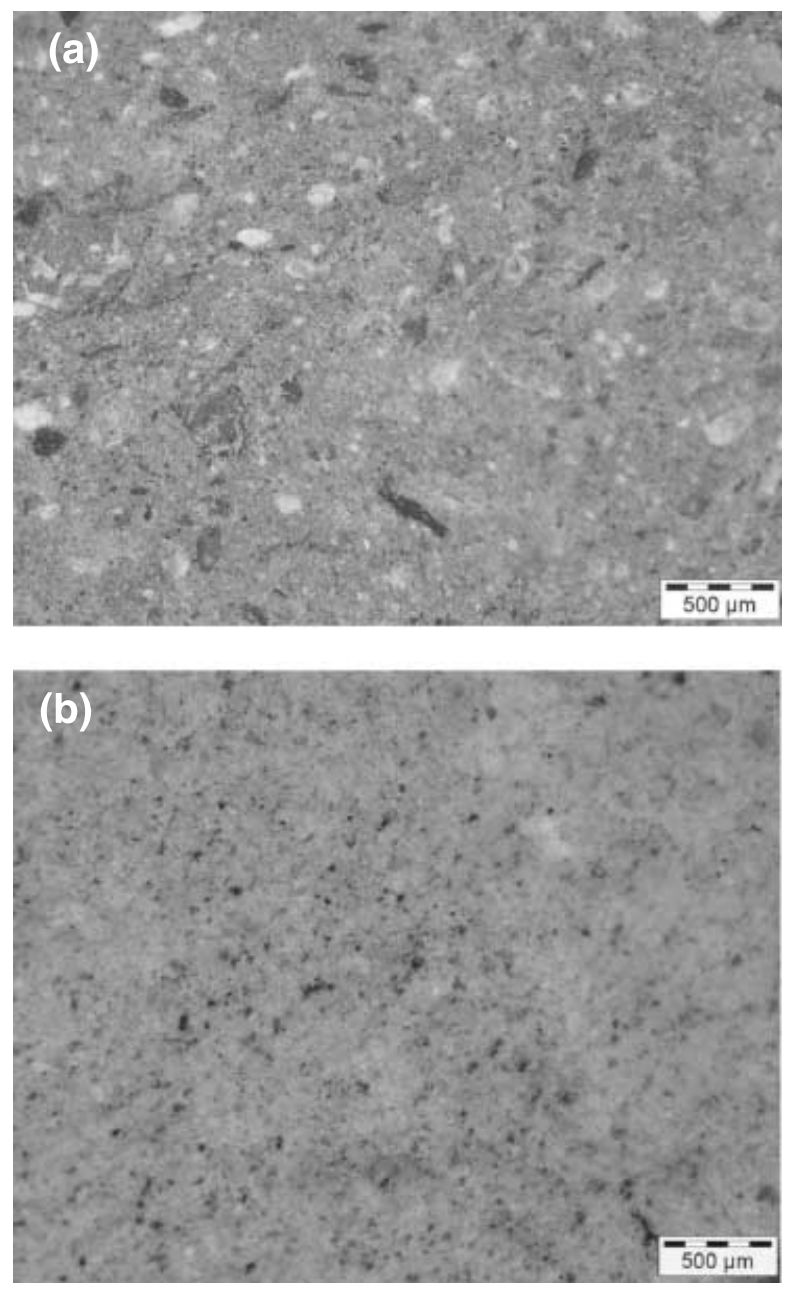

Figure 3 Metallic ware samples (a) with and (b) without MVIs.

from the 30 selected metallic ware samples, 30 standard ware samples as well as all available clay samples, seal impressions and the unbaked clay object were also included in the SR-XRD analysis. Table 1 shows the main mineral phases that were found in the samples of each group.

The clay minerals in the local soil samples are illite, kaolinite and montmorillonite, together with quartz and calcite. Apart from calcite, dolomite and plagioclase were also found. The raw materials that have been used for the seal impressions and the unbaked clay object show slight differences, but can still be regarded as very similar to the clay samples. The results show us that local resources are indeed rich in calcium. The large quantities of quartz and calcite confirm the idea that quartz and limestone inclusions were originally present in the clay that was used for local production of pottery.

Table 1 also shows a high degree of correlation between the phase composition of standard ware samples and that of the calcareous group of metallic ware samples (group 1). Some of 
Table 1 The mineral phase composition of clay samples, seal impressions, an unbaked clay object, standard ware and metallic ware from Tell Beydar

\begin{tabular}{|c|c|c|c|c|c|c|c|c|c|c|c|c|c|c|}
\hline & $Q^{*}$ & $\mathrm{Ca}$ & $P x$ & $M e$ & Plg & $K f s p$ & $M u$ & $\mathrm{He}$ & $\mathrm{Hem}$ & Mag & Dol & Ill & Kao & $M m$ \\
\hline Clay samples & $x x^{\dagger}$ & $\mathrm{xxx}$ & & & $\mathrm{x}$ & & & & & & $\mathrm{x}$ & $\mathrm{x}$ & $\mathrm{x}$ & $\mathrm{x}$ \\
\hline Seal impressions & $\mathrm{xx}$ & $\mathrm{xxx}$ & & & $\mathrm{x}$ & & & & & & $\mathrm{xx}$ & $x+$ & $\mathrm{x}$ & $x-$ \\
\hline Unbaked clay object & $\mathrm{xx}$ & $\mathrm{xxx}$ & & & $\mathrm{x}$ & & & & & & $\mathrm{x}$ & $\mathrm{x}+$ & $\mathrm{x}$ & $x-$ \\
\hline Standard ware & $\mathrm{xxx}$ & $(\mathrm{xx})$ & $\mathrm{xX}$ & $\mathrm{x}(\mathrm{x})$ & $x+$ & & & & $\mathrm{x}$ & & & & & \\
\hline Metallic ware 1 & $\mathrm{xxx}$ & $(\mathrm{xxx})$ & $\mathrm{xx}$ & $\mathrm{x}(\mathrm{x})$ & $\mathrm{x}$ & & & & & & & & & \\
\hline Metallic ware 2 & $\mathrm{xxx}$ & & & & & $\mathrm{x}$ & $\mathrm{x}$ & $\mathrm{x}$ & & & & & & \\
\hline Metallic ware 3 & $\mathrm{xxx}$ & & $\mathrm{x}(\mathrm{xx})$ & & $x x(x)$ & & & & $\mathrm{x}$ & $x(x)$ & & & & \\
\hline
\end{tabular}

\footnotetext{
*Q, quartz; Ca, calcite; Px, pyroxene; Me, melilite; Plg, plagioclase; Kfsp, K-feldspar; Mu, mullite; He, hercynite; Hem, hematite Mag, magnetite; Dol, dolomite; Ill, illite; Kao, kaolinite; Mm, montmorillonite.

$\dagger \mathrm{xxx}$, main phase; $\mathrm{xx}$, present in significant quantities; $\mathrm{x}$, present; brackets, only in some samples.
}

these samples contain calcite, but given the presence of substantial amounts of the hightemperature calcium silicates pyroxene and melilite $\left((\mathrm{Ca}, \mathrm{Na})_{2}(\mathrm{Al}, \mathrm{Mg}, \mathrm{Fe})(\mathrm{Si}, \mathrm{Al})_{2} \mathrm{O}_{7}\right)$, which are formed during firing above or at the temperature at which calcite decomposes, we can conclude that this calcite is of a secondary (post-depositional) origin. The presence of pyroxene, melilite and plagioclase indicates that firing temperatures must have reached at least $850^{\circ} \mathrm{C}$ (Maggetti 1982, 128). While virtually all standard ware samples exhibit hematite, this was never found in samples belonging to the first metallic ware group. Both the surface and the matrix of the latter are grey, indicating a reducing firing atmosphere, at least during the final stage of the firing cycle. This difference in firing atmosphere causes the presence or absence of hematite.

The non-calcareous metallic ware group clearly has a different phase composition, which is evidently related to its different chemical composition. Pyroxene, melilite and plagioclase are not found here. Instead, potassium feldspar, mullite and hercynite are the ceramic's constituents, next to quartz. The presence of mullite and hercynite indicates that the pottery was fired at a considerably higher temperature in a reducing atmosphere. Mullite is formed in non-calcareous clays, from about $1000^{\circ} \mathrm{C}$, while the formation of hercynite requires a reducing atmosphere at no less than $850-900^{\circ} \mathrm{C}$ (Grimshaw 1971, 718; Pradell 1999).

From a phase compositional point of view, the 'intermediate' metallic ware samples (group 3) seem to be more closely related to the calcareous samples (group 1) than to the non-calcareous ones (group 2). They also contain pyroxene, but less than those in the calcareous ones (except for two samples): they have no melilite, but are characterized by a larger amount of plagioclase. These different proportions of calcium silicates (when compared to the calcareous group) are not only caused by the lower amount of $\mathrm{CaO}$, but are most probably also a consequence of the lack of larger calcium-bearing inclusions in the intermediate group (while these were present in the calcareous group as limestone inclusions). Most samples in the intermediate group show both grey and orange colours, which can be explained by the presence of both magnetite and hematite.

In a last phase, 62 samples, of which 43 are metallic ware, were investigated using SEMEDX. The results are shown in Table 2 and indicate that the overall composition of the calcareous metallic ware and that of the standard ware are very similar. The difference in $\mathrm{SO}_{3}$ might result from a difference in firing conditions. While porosity increases during firing until about $750-850^{\circ} \mathrm{C}$, 
Table 2 The average elemental composition of Tell Beydar and Tell Brak samples as revealed by SEM-EDX (S.D. in brackets)

\begin{tabular}{lcccccccccc}
\hline \hline Sample & $\mathrm{Na}_{2} \mathrm{O}$ & $\mathrm{MgO}$ & $\mathrm{Al}_{2} \mathrm{O}_{3}$ & $\mathrm{SiO}_{2}$ & $\mathrm{~K}_{2} \mathrm{O}$ & $\mathrm{CaO}$ & $\mathrm{SO}_{3}$ & $\mathrm{TiO}_{2}$ & $\mathrm{Fe}_{2} \mathrm{O}_{3} \mathrm{t}$ \\
\hline $\begin{array}{l}\text { Calcareous metallic ware } \\
(n=14)\end{array}$ & $0.8(0.3)$ & $5.0(0.7)$ & $12.2(0.8)$ & $49(3)$ & $2.8(0.6)$ & $21(4)$ & b.d.1.* & $0.7(0.2)$ & $8(1)$ \\
$\begin{array}{l}\text { Non-calcareous metallic ware } \\
(n=21)\end{array}$ & $0.6(0.4)$ & $1.8(0.5)$ & $20(2)$ & $61(4)$ & $4(1)$ & $3(1)$ & $1(1)$ & $1.1(0.2)$ & $7(2)$ \\
$\begin{array}{l}\text { Intermediate metallic ware } \\
(n=8)\end{array}$ & b.d.1. & $5(1)$ & $15(2)$ & $59(3)$ & $2.6(0.8)$ & $9(5)$ & b.d.1. & $0.9(0.1)$ & $9(1)$ \\
\begin{tabular}{l} 
Standard ware $(n=16)$ \\
\hline \hline
\end{tabular} & b.d.1. & $5(1)$ & $13(1)$ & $47(3)$ & $2.4(0.9)$ & $19(5)$ & $4(2)$ & $0.7(0.2)$ & $8(2)$ \\
\hline
\end{tabular}

*B.d.l. = below detection limit.

it will start to decrease when the temperature exceeds about $900^{\circ} \mathrm{C}$, due to (partial) fusing and vitrification. Eventually, the fused matter will start to fill pores, thereby decreasing the porosity (Grimshaw 1971, 816-17). Moreover, initial vitrification occurs slightly earlier in a reducing atmosphere (Maniatis and Tite 1981, 65). Thus, calcareous metallic ware, being fired in a mainly reducing atmosphere and at higher temperatures than standard ware (which was fired in a neutral to oxidizing atmosphere), is less porous and might therefore contain less $\mathrm{SO}_{3}$. All of this suggests that although two different firing technologies were used (elevated temperatures in a usually reducing atmosphere versus moderate temperatures in a neutral to oxidizing atmosphere), calcareous metallic ware and standard ware were made using similar raw materials. Although trace element concentrations are not available yet, this result may confirm the idea that the calcareous metallic ware is a local imitation of 'real' non-calcareous metallic ware.

\section{DISCUSSION AND CONCLUSIONS}

It is clear that three groups of metallic ware exist at Tell Beydar. They differ from each other from a petrological, phase compositional and chemical point of view, even though the image of the 'intermediate' chemical group might be a bit diffuse. Generalizing, we can state the following:

(1) calcareous metallic ware = petrological group 1 (samples with MVIs);

(2) non-calcareous metallic ware = petrological group 2 (samples without MVIs);

(3) intermediate metallic ware = petrological group 3 (samples with hardly any inclusions).

Kühne and Schneider have already stated that calcareous metallic ware can be partly differentiated in the field from non-calcareous metallic ware on the basis of the surface and matrix colour (Kühne and Schneider 1988, 114ff.). We have shown that not only the surface and/or the matrix colour can be used, but also, and moreover, the presence of macroscopically visible inclusions (inclusions that can be seen by the naked eye or using a hand lens $(\times 10)$ ) should be used as an indicator.

Kühne and Schneider's chemical group 4 corresponds to our intermediate group. In their study too, these samples were chemically more affiliated with the calcareous samples, while they showed more visual resemblance to the non-calcareous samples (Kühne and Schneider 1988, 114ff.). Using their criteria, chemical analyses were needed to identify them. Our results 
make it possible to distinguish this intermediate group using polarizing microscopy, without the need for chemical analyses. However, the question of how to identify this pottery in the field remains unanswered.

The mineralogical and chemical similarities between this metallic ware group and standard ware, and the chemical match between these two wares and local clay samples, might strengthen the idea that calcareous metallic ware is a local (or at least regional) imitation of 'real' non-calcareous metallic ware. These imitations already occur-at least, at Tell Beydarin the earliest metallic ware levels. Therefore, we think that one can exclude the eventual exhaustion or inaccessibility of the non-calcareous raw materials as the initial reason for the production of imitations (Kühne and Schneider 1988, 118).

It is evident that what we have termed non-calcareous metallic ware must have been a valuable product. Although metallic ware makes up only a minor proportion within the total assemblage of pottery, much of the pottery that is found as funerary gifts is metallic ware, even though it is often accompanied by standard ware (at this stage, we do not have enough information to say whether only 'real' metallic ware vessels accompanied the dead to the afterlife, or whether imitations were also good enough). We can assume that this value, which is indeed linked to its 'exotic' character, was the reason for the early start of the local or regional production of imitations. It is worth noting that, judging from our set of samples, calcareous imitations are not just a small minority (Schneider 1989, 34), but represent about one third of the samples, while less than half of our samples from Tell Beydar are 'real' noncalcareous metallic ware.

The bulk of the non-calcareous samples from Tell Beydar seem to belong to Schneider's non-calcareous group B. Only two of our samples from Tell Beydar probably belong to group A (together with one from Tell Brak and one from Tell Jemello). Knowing that most samples from Tell Brak that have been analysed in the past belong to group B (Schneider 1989, 38), our findings come as no surprise, given the political and economical ties between Nabada (Tell Beydar) and Nagar (Tell Brak). However, the question still remains: Where does 'real' metallic ware come from? Given the existence of two compositional subgroups, it is believed that two clay sources were exploited, supposedly situated somewhere in the Taurus foothill zone (Schneider 1989, 34).

\section{ACKNOWLEDGEMENTS}

The authors would like to thank Dr David Williams for enabling us to do the petrographical research at the Archaeology Department of the University of Southampton. We thank Professor Raoul Ottenburgs, of Leuven University's Department of Physico-Chemical Geology, for letting us use their petrology imaging facilities. This paper presents research results financed by the Special Research Fund of the University of Antwerp (New Research Initiative), FWO-Vlaanderen and the 'Interuniversity Poles of Attraction Program-Belgian State, Federal Office for Scientific, Technical and Cultural Affairs' and fits within the objectives of COST Action G8.

\section{REFERENCES}

Braidwood, R. J., and Braidwood, L. S., 1960, Excavations in the Plain of Antioch I: the earlier assemblages phases $A-J$, Oriental Institute Publications 61, University of Chicago Press, Chicago.

Broekmans, T., Adriaens, A., and Pantos, E., 2004, Analytical investigations of cooking pottery from Tell Beydar (NE-Syria), Nuclear Instruments and Methods B, 226, $92-7$.

Grimshaw, R. W., 1971, The chemistry and physics of clays and allied ceramic materials, John Wiley, New York. 
Kühne, H., 1976, Die Keramik vom Tell Chuera und ihre Beziehungen zu Funden aus Syrien-Palästina, der Türkei und dem Iraq, Gebrüder Mann Verlag, Berlin.

Kühne, H., and Schneider, G., 1988, Neue Untersuchungen zur Metallischen Ware, Damaszener Mitteilungen, 3, 83139.

Lebeau, M., and Suleiman, A. (eds.), 1997, Tell Beydar, three seasons of excavations (1992-1994). A preliminary report, Subartu, 3, Brepols, Turnhout.

Maggetti, M., 1982, Phase analysis and its significance for technology and origin, in Archaeological ceramics (eds. J. S. Olin and A. D. Franklin), 121-33, Smithsonian Institution Press, Washington, DC.

Maniatis, Y., and Tite, M. S., 1981, Technological examination of Neolithic - Bronze Age pottery from central and southeast Europe and from the Near East, Journal of Archaeological Science, 8(1), 59-76.

Mellaart, J., 1966, Anatolian pottery as a basis for cultural synthesis, in Ceramics and man (ed. F. R. Matson), $218-$ 39, Methuen, London.

Oates, D., Oates, J., and McDonald, H. (eds.), 2001, Excavations at Tell Brak, vol. 2: Nagar in the third millennium $B C$, University of Cambridge, Cambridge/The British School of Archaeology in Iraq, London.

Pradell, T., 1999, Ceramic evolution during a reductive firing, in 4th European Meeting on Ancient Ceramics. Archaeological and archaeometric studies (ed. Govern d'Andorra), 334-50, Ministeri de Turisme i Cultura, Andorra.

Schneider, G., 1989, A technological study of North-Mesopotamian stone ware, World Archaeology, 21(1), 30-50.

Schneider, G., and Daszkiewicz, M., 2001, Stone ware and Ninevite 5-notes on composition and technology of pottery from Tell Brak, in Excavations at Tell Brak, vol. 2: Nagar in the third millennium BC (eds. D. Oates, J. Oates and H. McDonald), 194-216, University of Cambridge, Cambridge/The British School of Archaeology in Iraq, London.

van As, A., and Jacobs, L., 1997, A technological classification of the Early Dynastic and Old Akkadian pottery of Tell Beydar, Syria, Newsletter of the Department of Pottery Technology (Leiden University), 14/15, 49-67. 